\title{
Potent natural products and herbal medicines for treating liver fibrosis
}

\author{
Shao-Ru Chen, Xiu-Ping Chen, Jin-Jian Lu, Ying Wang ${ }^{*}$ and Yi-Tao Wang*
}

\begin{abstract}
Liver fibrosis is a wound-healing response to chronic liver injury characterized by progressive inflammation and deposition of extracellular matrix components. The pathological condition of liver fibrosis involves secretion of extracellular matrix proteins and formation of scar tissue. The major regulators involved in hepatic fibrogenesis are the transforming growth factor (TGF)-B1/SMAD and toll-like receptor 4 (TLR4)-initiated myeloid differentiation primary response 88 gene (MyD88)/NF-kB cell signaling pathways. This article reviews natural products and herbal medicines that have demonstrated activity against liver fibrosis through different mechanisms of action, including anti-hepatitis B and $C$ virus activity, anti-inflammation, inhibition of cytokine production and nuclear receptor activation, and free radical scavenging.
\end{abstract}

\section{Introduction}

Chronic liver injury increases extracellular matrix (ECM) deposition by activating the hepatic stellate cells (HSCs). This results in liver fibrosis, which is a major cause of mortality worldwide mainly because of chronic infection with the hepatitis virus and obesity associated with fatty liver disease [1]. Cirrhosis occurs in the final stage of liver fibrosis and is characterized by the distortion of liver vasculature and architecture that increases the likelihood of liver failure and primary liver cancer [2]. At present, there are no medications to manage liver fibrosis; the only treatment is tissue transplantation. The range of biological activities offered by natural products and herbal medicines has increased interest in their potential for treating liver fibrosis.

We review natural products and herbal medicines that have demonstrated activity against liver fibrosis through different mechanisms of action, including anti-hepatitis B and $C$ virus activity, anti-inflammation, inhibition of cytokine production and nuclear receptor activation, and free radical scavenging. PubMed and Google Scholar were searched for references before the end of 2014 using the following combination of keywords: liver fibrosis and natural product; liver fibrosis and herbal medicine; liver fibrosis and Chinese medicine; liver fibrosis and Clinical trials; liver fibrosis and mechanism of action.

\footnotetext{
* Correspondence: emilyywang@umac.mo; ytwang@umac.mo State Key Laboratory of Quality Research in Chinese Medicine, and Institute of Chinese Medical Sciences, University of Macau, Macao, SAR, China
}

\section{Pathogenesis and molecular signaling pathways involved in liver fibrosis \\ Pathogenesis of liver fibrosis}

Liver fibrosis is a wound-healing response to chronic liver injury involving accumulated inflammation, which leads to the increased deposition of ECM and scar tissue [3]. It progresses at different rates in patients with various types of chronic liver injury [3]. Principal collagenproducing cells in the fibrotic liver include activated HSCs, portal fibroblasts, and myofibroblasts of bone marrow origin $[4,5]$. Among them, activated myofibroblasts are most responsible for forming fibrotic tissue associated with most chronic liver diseases [6]. The precise origin of activated myofibroblasts is unknown, but several types of cell may be implicated. Bone marrow-derived fibrocytes, or circulating mesenchyme cells, migrate through the injured liver and differentiate into myofibroblasts during fibrogenesis [7]. In addition, hepatocytes, sinusoidal endothelial cells, Kupffer cells, and lymphocytes may contribute to liver fibrosis [7].

Under normal conditions, HSCs store retinoid and remain in a quiescent state, with expression of adipocyte markers, including peroxisome proliferation-activated receptor- $\gamma$ (PPAR- $\gamma)$, sterol regulatory element binding protein-1c, and leptin [8]. HSCs are activated to produce different types of ECM proteins in conditions of chronic inflammation [9]. Activated HSCs are characterized by myogenic markers like $\alpha$-smooth muscle actin ( $\alpha$-SMA), c-Myb, and myocyte enhancer factor-2 [10]. 
TGF- $\beta 1$ governs liver fibrosis

TGF- $\beta 1$ is a member of the TGF $\beta$ superfamily [11] and is involved in liver fibrosis (Figure 1A). Under normal conditions, TGF- $\beta 1$ binds to latency-associated peptide and remains inactivated. Upon activation, TGF- $\beta 1$ binds to its receptors and phosphorylates the downstream signal
SMAD2/3. Phosphorylated SMAD2/3 recruits the common mediator SMAD4 to form a hetero-oligomer complex. The SMAD complex then translocates into the nucleus and activates transcription of collagens [12]. Elevated collagen expression induces trans-differentiation of myofibroblasts, which secrete ECMS that can overwhelm

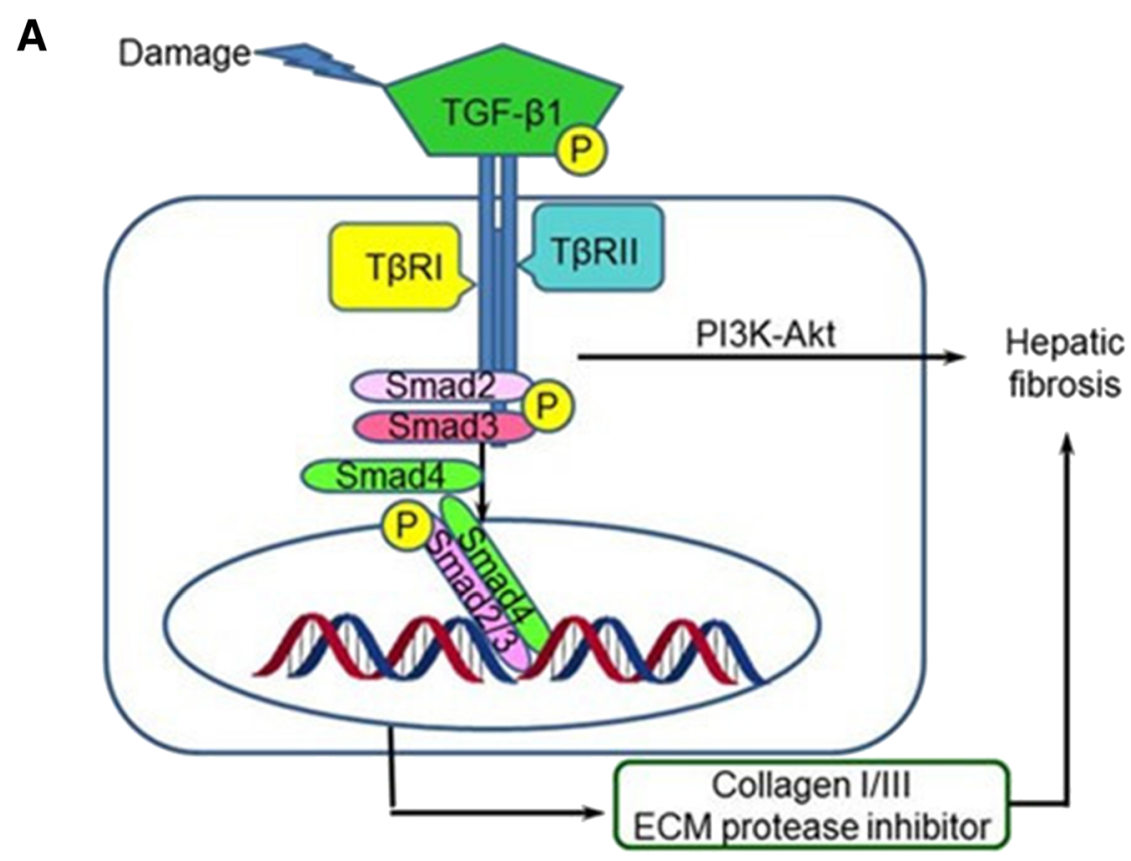

B

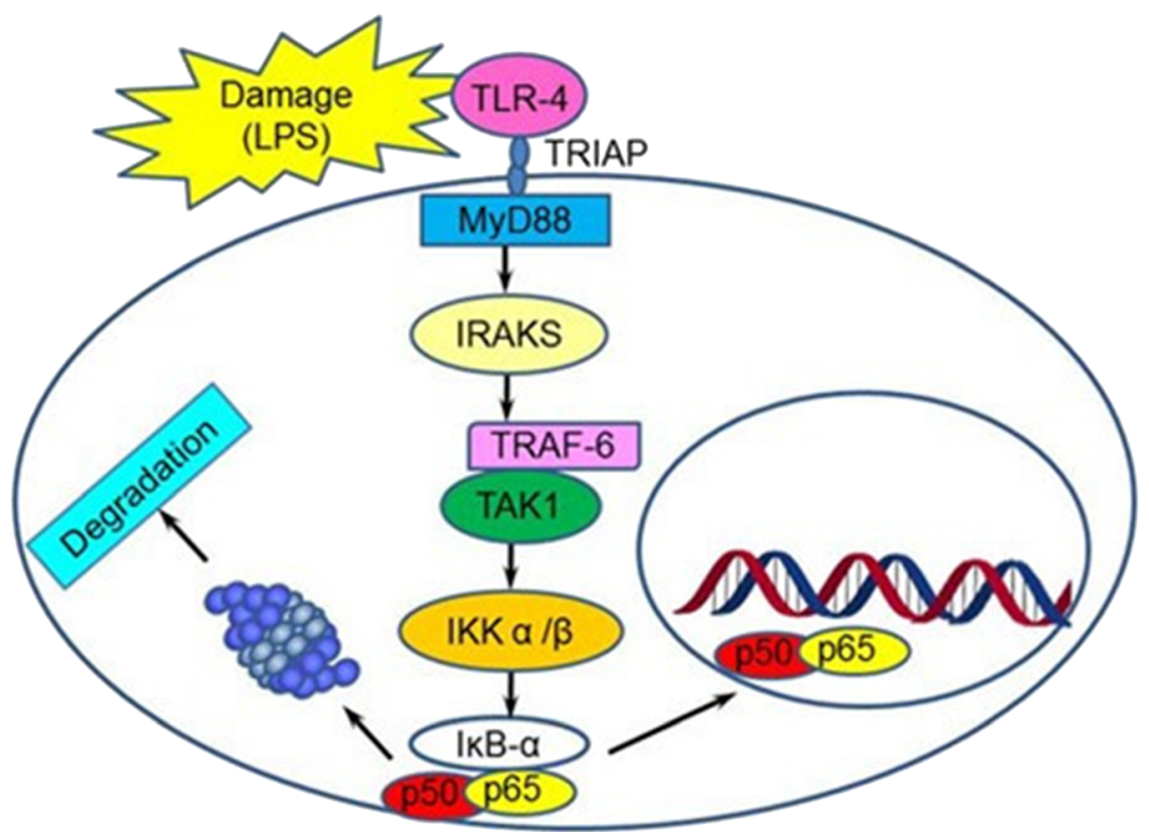

Figure 1 Signaling pathway mediates hepatic fibrogenesis: (A) the TGF- $\beta 1 / S M A D$ signaling pathway, and (B) TLR4 activated-MyD88/TGF $31 / N F K B$ pathway. 
the cellular capacity for ECM degradation and lead to fibrosis [13].

Sustained signaling from the TGF- $\beta 1$ cascade proliferates HSCs, which also produce ECMs, resulting in fibrous scars [4]. TGF- $\beta 1$ stimulates myofibroblast differentiation through the phosphatidylinositol 3-kinase (PI3K)-Akt pathway. Upon liver damage, TGF- $\beta 1$ activates Akt signaling via $\mathrm{p} 38$ mitogen-activated protein kinase and focal adhesion kinase (FAK). Prolonged activation of the above cell signaling pathways ultimately leads to inflammatory conditions in the liver, resulting in liver fibrosis [14].

\section{TLR4 promotes liver fibrosis through transcription of inflammation cytokines}

Almost all hepatic cells with elevated levels of TLR4 are related to fibrotic progression (Figure 1B) and promote liver fibrosis [15]. TLR4 induces transcription of genes related to fibrogenesis through the MyD88/NFkB cascade [16]. Upon damage, lipopolysaccharide (LPS) interacts with circulating LPS-binding protein and binds to TLR4 through the co-receptors cluster of differentiation 14 (CD14) and lymphocyte antigen 96 [17]. The LPS/TLR4 complex then activates downstream pathways via the bridging adaptor TIR-domain-containing adaptor protein (TRIAP) dependent on MyD88 or the TIR-domain-containing adapter-inducing interferon- $\beta$ (TRIF).

In a MyD88-dependent manner, MyD88 recruits IRAK4 (IL-1 receptor associated-kinase-4) through an interaction between their death domains. Once activated, IRAK4 triggers further activation of IRAK1 and IRAK2. The activated IRAKs then dissociate from the MyD88 complex and interact with tumor necrosis factor receptor-associated factor-6 (TRAF6). The IRAKs/ TRAF6 complex binds to TAK1 (TGF- $\beta$ activated kinase 1), which subsequently leads to phosphorylation and ubiquitination of subunits of the IкB kinase complex. Then NF-кB will be released from the ІкB kinase complex and translocate into the nucleus after IкB $\alpha$ phosphorylated and ubiquitinated [18], inducing transcription of inflammatory cytokines related to liver fibrogenesis, including interleukin 6 (IL-6), IL-12, and tumor necrosis factor $\alpha$ (TNF $\alpha)$ [19].

In the TRIF-dependent signaling pathway, LPS activates the receptors and recruits the adaptor TRIF. Subsequently, TRIF activates TANK-binding kinase 1 (TBK1) and receptor-interacting protein 1 (RIP1). The TRIF/TBK1 signaling complex then phosphorylates interferon (IFN) regulatory factor 3 (IRF3). The phosphorylated IRF3 translocates into the nucleus and activates transcription of type I IFN. The activated RIP1 also triggers polyubiquitination and activation of TAK1 and NF-kB.

\section{Bile acid homeostasis and xenobiotic detoxification receptors}

Nuclear receptors and cell surface receptors regulate the initiation and progress of liver fibrosis [20]. Bile acid regulates hepatic lipid metabolism through binding to its nuclear receptor farnesoid X receptor (FXR) [21]. Bile acid-activated FXR induces transcription of repressor small heterodimer partner mRNA (SHP). SHP then binds to liver receptor homolog-1 and inhibits the expression of cholesterol $7 \alpha$-hydroxylase $\left(\mathrm{CYP}_{7} \mathrm{~A}_{1}\right.$, or cytochrome P4507A1). Decreased $\mathrm{CYP}_{7} \mathrm{~A}_{1}$ expression suppresses the multiple-step conversion of cholesterol to primary bile acid (or cholic acid) and thus attenuates the progression of liver fibrogenesis [22]. SHP also binds to retinoid $\mathrm{X}$ receptor $\alpha(\mathrm{RXR} \alpha)$ and retinoic acid receptor (RAR), which represses synthesis of the hepatic bile salt and thus reduces one of the contributing factors of liver fibrosis [23]. The activated FXR bound to SHP also promotes quiescence and apoptosis of activated HSCs in the fibrotic liver [24].

Bile acid also activates vitamin D receptor (VDR), a member of the nuclear hormone receptor superfamily [25]. Together with FXR, VDR regulates bile acid homeostasis and xenobiotic detoxification in the liver. VDR ligands prevent liver fibrosis by deactivation of HSCs through downregulation of the TGF- $\beta 1 /$ SMAD pathway [25].

\section{Other cell signaling pathways involved in liver fibrosis}

The FAK PI3K-Akt signaling pathway plays a major role in the activation of HSCs [26]. The PI3K complex consists of a p110 catalytic subunit and a p85 regulatory subunit. The activated PI3K catalyzes the reaction to produce Ptdlns(3,4,5)P3 and Ptdlns(3,4)P2, which bind to the pleckstrin homology domain of Akt and trigger its plasma membrane translocation and activation. Fully activated Akt promotes proliferation and survival in HSCs and other cell types [27].

The PPAR pathway is closely related to the activation of HSCs in liver fibrosis [28]. PPAR- $\gamma$, a key regulator of connective tissue homeostasis, inhibits fibrogenesis in HSCs and attenuates liver fibrosis in vivo [28]. The expression of PPAR- $\gamma$ is mainly regulated by the TGF$\beta 1 /$ SMAD signaling pathway [29]. Other transcription factors like nuclear factor-like 2 (Nrf2) and cytokines (TNF- $\alpha$, IL-6, IL-13) can also activate HSCs and promote liver fibrosis [30].

\section{Free radicals induce liver damage}

Reactive oxygen species (ROS) are related to chronic liver damage and fibrogenesis [31]. ROS stimulate expression of cytokines, hormones, and growth factors and ROS-generated cytokines like platelet-derived growth 
factor (PDGF) and TGF- $\beta 1$ are closely related to hepatic fibrogenesis [32].

\section{The balance of EMT and MET governs hepatic fibrogenesis}

Epithelial-mesenchymal transition (EMT) is the process by which epithelial cells lose apicobasal polarity and intercellular adhesion complexes change phenotypes dramatically and move through the ECM like mesenchymal cells [33]. The balance between EMT and its reverse process, mesenchymal-to-epithelial transition (MET), determines the progression of liver fibrosis [33]. EMT is usually triggered by the growth factors-induced expression of Snail and TM4SF5 [34]. The activated HSCs in the fibrotic liver also undergo an EMT as revealed by elevated mesenchymal and epithelial markers [35]. Other regulators, such as cadherins, microRNAs, transcription factors (e.g., Pax, paraxis, and Fox) and growth factors (e.g., Wnts, FGFs, and ephrins) are also involved in maintaining the balance of EMT and MET [36,37].

\section{Commonly used liver fibrosis animal models}

Laboratory animal models are based on the above pathological and molecular background of hepatic fibrosis.
The most commonly used laboratory liver injury model is induced by chemical reagents like carbon tetrachloride $\left(\mathrm{CCl}_{4}\right)$ or alcohol. Transgenic animal models manipulate the expression of key signaling molecules like TGF- $\beta 1$ to mimic the pathological condition of liver fibrosis. We summarize the most commonly used animal models in Table 1.

\section{Potent natural products and herbal medicines for the management of liver fibrosis}

From Table 2, we can see that there are a lot of potent natural products and herbal medicines for the management of liver fibrosis. But effective therapeutic options are limited in liver fibrosis [38]. Because of its diverse pathogenetic mechanisms, its management may include antiviral or anti-inflammatory approaches, inhibition of cytokine production, modulation of nuclear receptors, reduction of cellular oxidative stress, and EMT and MET balance.

\section{Antiviral drugs attenuate chronic hepatitis infection}

Chronic hepatitis $\mathrm{B}$ and $\mathrm{C}$ virus ( $\mathrm{HBV}$ and $\mathrm{HCV}$ ) infection is the leading cause of liver fibrosis. Nucleoside/nucleotide analogs like Entecavir or Lamivudine are used

Table 1 Commonly used animal models in the study of liver fibrosis

\begin{tabular}{|c|c|c|c|c|}
\hline Model & $\begin{array}{l}\text { Inducing } \\
\text { factor }\end{array}$ & Methodology & Characteristics & Reference \\
\hline $\begin{array}{l}\text { Bridging fibrosis } \\
\text { mice }\end{array}$ & $\mathrm{CCl}_{4}$ & $\begin{array}{l}\text { Eight-week-old male C } 57 \mathrm{BL} / 6 \mathrm{~J} \text { mice are } \\
\text { intraperitoneally injected with } 0.5-\mathrm{ml} / \mathrm{kg} \text { body } \\
\text { weight } \mathrm{CCl} 4 \text { ( } 1: 50 \mathrm{v} / \mathrm{v} \text { in corn oil) or vehicle (DMSO } \\
\text { in corn oil) three times a week for } 4 \text { weeks. } \\
\text { Calcipotriol (20- } \mu \mathrm{g} / \mathrm{kg} \text { body weight) is administrated } \\
\text { by oral gavage five times a week, commencing } \\
20 \text { days after the first dose of } \mathrm{CCl}_{4}\end{array}$ & $\begin{array}{l}\text { Convenient, reproducible, well tolerated, } \\
\text { most commonly used model }\end{array}$ & [115] \\
\hline $\begin{array}{l}\text { Alcohol-induced } \\
\text { fibrosis }\end{array}$ & Alcohol & $\begin{array}{l}\text { Alcohol in combination with Western diet is fed to } \\
\text { mice intragastrically for } 8 \text { weeks }\end{array}$ & $\begin{array}{l}\text { Aversion for alcohol, rapid metabolism, } \\
\text { difficult to control fibrotic stage }\end{array}$ & [116] \\
\hline $\begin{array}{l}\text { Non-alcoholic } \\
\text { steatohepatitis } \\
\text { (NASH)-associated } \\
\text { fibrosis }\end{array}$ & $\begin{array}{l}\text { Methionine and } \\
\text { Choline }\end{array}$ & $\begin{array}{l}\text { Female C57BL } / 6 \text { mice are fed a methionine-choline- } \\
\text { deficient diet or a methionine-choline- } \\
\text { supplemented diet for } 10 \text { weeks; the latter control } \\
\text { diet is composed of MCD diet supplemented with } \\
\text { L-methionine }(1.7 \mathrm{~g} / \mathrm{kg}) \text { and choline bitartrate } \\
(14.48 \mathrm{~g} / \mathrm{kg})\end{array}$ & $\begin{array}{l}\text { Similar pathology to human NASH, well } \\
\text { characterized, highly reproducible, lack of } \\
\text { metabolic context, time consuming }\end{array}$ & [117] \\
\hline $\begin{array}{l}\text { Auto-immune } \\
\text { fibrosis }\end{array}$ & Pig serum & $\begin{array}{l}\text { Male Wistar rats are given intraperitoneal injections } \\
\text { of } 0.5-\mathrm{ml} \text { normal pig serum twice a week for } \\
10 \text { weeks with or without concomitant oral } \\
\text { administration of PTX }(20 \mathrm{mg} / \mathrm{kg})\end{array}$ & $\begin{array}{l}\text { Mimics immunologic component, but } \\
\text { lack of stability and time consuming }\end{array}$ & [118] \\
\hline Biliary fibrosis & $\begin{array}{l}\text { Bile duct } \\
\text { ligation }\end{array}$ & $\begin{array}{l}\text { Under methoxyflurane anesthesia, the common bile } \\
\text { duct is double-ligated using } 4-0 \text { silk after a midline } \\
\text { abdominal incision. Sham-operated mice have their } \\
\text { common bile duct exposed and manipulated but } \\
\text { not ligated }\end{array}$ & $\begin{array}{l}\text { Reversible, but highly variable with high } \\
\text { mortality rate }\end{array}$ & [119] \\
\hline $\begin{array}{l}\text { CRP-TGF- } \beta 1, \text { IL-12p35 } \\
-- \text { dnTGF } \beta R \\
\text { transgenic-genetic } \\
\text { model }\end{array}$ & $\begin{array}{l}\text { Overexpression } \\
\text { of TGF- } \beta 1\end{array}$ & Standard transgenic method & $\begin{array}{l}\text { TGF- } \beta 1 \text { susceptibility, pathophysiological } \\
\text { significance, but expensive, and early } \\
\text { death with limited application }\end{array}$ & {$[120]$} \\
\hline $\begin{array}{l}\text { Mdr2 }\left(\mathrm{Abcb}^{-/-}\right) \\
\text {transgenic-genetic } \\
\text { model }\end{array}$ & $\begin{array}{l}\text { Hepatobiliary } \\
\text { phosphatidyl- } \\
\text { choline }\end{array}$ & Standard transgenic method & $\begin{array}{l}\text { Hepatic lesions resembling primary } \\
\text { sclerosing cholangitis, convenient but } \\
\text { expensive }\end{array}$ & [121] \\
\hline
\end{tabular}


Table 2 Pharmacological effects of natural products and herbal medicines with anti-liver fibrosis activity

\begin{tabular}{|c|c|}
\hline $\begin{array}{l}\text { Natural product/ } \\
\text { herbal medicine }\end{array}$ & Pharmacological effect \\
\hline Helioxanthin & $\begin{array}{l}\text { Inhibited HBV replication, suppressed IL-1-induced } \\
\text { c-jun transcription and c-jun-mediated DNA binding activity of AP- }\end{array}$ \\
\hline Wogonin & $\begin{array}{l}\text { Suppressed secretion of HBV antigens and reduced HBV DNA level } \\
\text { through inhibition of HBV DNA polymerase activity }\end{array}$ \\
\hline $\begin{array}{l}\text { Matrine and } \\
\text { oxymatrine }\end{array}$ & $\begin{array}{l}\text { Inhibited HBV surface antigen secretion, E antigen, and HBV DNA } \\
\text { replication }\end{array}$ \\
\hline $\begin{array}{l}\text { Rhodiola kirilowii } \\
\text { Maxim }\end{array}$ & Inhibited HCV NS3 serine protease activity \\
\hline Green tea & Inhibited HCV viral entry and replication \\
\hline
\end{tabular}

Glycyrrhizin acid

Inhibited HCV full-length viral particle and HCV core gene expression syngenetically with IFNa, reduced hepatic inflammation, prevented apoptosis and inflammatory infiltrates

Nobiletin Inhibited HCV absorption, reduced hepatic inflammation

Genistein

Salvianic acid A

Betulin, betulinic acid

Gexia Zhuyu Tang

Yanggan Wan

Rosmarinic acid, baicalin

Yin Chen Hao

Tang

Paeoniflorin

Oleanolic acid, ursolic acid

Silymarin

Silybinin

Acanthus ilicifolius alkaloid A

Curcumin

$\beta$-caryophyllene

Diwu Yanggan formula

Decreased levels of inflammation mediators, including IL-6, TNFa and myeloperoxidase

Inhibited proliferation of HSCS, reduced expression of TGF- $\beta 1$ and collagen $|/|||$

Inhibited expression of TNFa, TGF- 31 , TIMP-1, TIMP-2, and MMP-2

Attenuated fibrogenesis and reduced inflammation, reduced $\mathrm{CCl}_{4}$ induced collagen deposition

Deactivated HSCs through epigenetic de-repression of PPAR- $\gamma$

De-repressed PPAR- $\gamma$ through suppression of canonical Wnt signal-

Decreased serum IFN- $\gamma$ and IL-12 levels, inhibited a-SMA activation and transcription of its target genes

Reduced the size of egg granuloma, fibrosis scores, serum IL-13 levels, and hydroxyproline content, and blocked IL-13 signaling pathway and its coactivator SRC-3 and endogenous ligand chenodeoxycholic acid, suppressed expression of FXR-targeted bile salt export protein, reduced hepatic free radicals through increasing hepatic transcription of Nrf2 target genes

Protected liver from further damage through antioxidant and antiinflammatory activity

Inhibited TGF- $\beta 1$-induced collagen secretion and oxidase stress

Reduced lipid peroxidation and oxidative stress cannabinoid receptors, inhibited ECM expression, decreased collagen deposition, increased serum MMP-13 and glutathione levels

Exhibited high scavenging activity against hydroxyl radicals and superoxide anions, inhibited lipid peroxidation, suppressed expression of Col1a1 and TIMP-1

\section{Model system}

HBV-producing HepG 2.2.15 cell line

HBV-producing MS-G2 cell line

HBV-producing HepG 2.2.15 cell line

Cos-7(NS3/4A-SEAP) cell line

Primary human hepatocyte cells infected with HCV pseudoparticles, HCV-JFH1 viral culture system, patients with HCV infection and detectable viremia

HCV-infected liver cells, BALB/C mice

Human lymphoblastoid leukemia MOLT-4 cell line, and primary cultured rat hepatocytes

$\mathrm{CCl}_{4}$-induced rat hepatic fibrosis ing in activated HSCs

Inhibited bile acid production by blocking the interaction between FXR

HSC-T6 cell line

[61]

Alcohol-induced liver fibrosis

Late-stage liver fibrosis patients, $\mathrm{CC}_{4}^{-}$ induced mouse liver fibrosis

Bile duct-induced cholestatic mouse liver fibrosis

Bile duct-induced cholestatic mouse liver fibrosis

Rat liver fibrosis model

$\mathrm{CCl}_{4}$-induced rat hepatic fibrosis

HepG2 cell line, wild-type and Nrf2-null [80-82] mice

$\mathrm{CCl}_{4}$-induced rat liver fibrosis

Thioacetamide-induced rat liver fibrosis

[86]

$\mathrm{CCl}_{4}$-induced mouse liver fibrosis

$[87,88]$

CCl4-induced rat liver fibrosis

$\mathrm{CCl}_{4}$-induced mouse liver fibrosis

$\mathrm{CCl}_{4}$-induced rat liver fibrosis 
Table 2 Pharmacological effects of natural products and herbal medicines with anti-liver fibrosis activity (Continued)

\begin{tabular}{|c|c|c|c|}
\hline Salvianolic acid B & Abrogated EMT-induced fibrogenesis & Renal fibrosis model & {$[96]$} \\
\hline $\begin{array}{l}\text { Fuzheng Huayu } \\
\text { tablet }\end{array}$ & $\begin{array}{l}\text { Reversed EMT in the fibrotic kidney through suppression of a-SMA, } \\
\text { TGF- } \beta 1 \text {, and nuclear translocation of SMAD3; induced apoptosis } \\
\text { through p38 and SAPK JNK pathways; decreased transcription of } \\
\text { TIMP-1, PDGF-B, and PDGF receptor } \beta 1 \text {; reversed HBV-induced fibrosis } \\
\text { and cirrhosis; prevented TGF- } \beta 1 \text {-induced EMT }\end{array}$ & $\begin{array}{l}\text { Renal fibrosis model, HSC-T6 cells, pa- } \\
\text { tients with chronic hepatitis B, patients } \\
\text { with cirrhosis caused by hepatitis B, } \\
\text { renal fibrosis rats }\end{array}$ & {$[95,97-105,122,123]$} \\
\hline $\begin{array}{l}\text { Fufang Biejia } \\
\text { Ruangan pill }\end{array}$ & Downregulated TGF- $\beta 1 / S M A D$ pathway transduction & Rats, HSC-T6 cell line, and clinical trial & {$[45,49]$} \\
\hline $\begin{array}{l}\text { Silybin- } \\
\text { phospholipids } \\
\text { and vitamin E } \\
\text { complex }\end{array}$ & $\begin{array}{l}\text { Reduced liver fibrosis scores and downregulated fibrosis markers, } \\
\text { deactivated HSCs and downregulated TGF- } \beta 1 \text { and TNFa }\end{array}$ & $\begin{array}{l}\text { Fatty liver-associated HCV-positive } \\
\text { patients }\end{array}$ & {$[109,110]$} \\
\hline Obeticholic acid & $\begin{array}{l}\text { Inhibited synthesis and accumulation of bile acid in the liver, } \\
\text { reduced liver inflammation and fibrosis }\end{array}$ & $\begin{array}{l}\text { Patients with type } 2 \text { diabetes and non- } \\
\text { alcoholic fatty liver disease }\end{array}$ & {$[111,112]$} \\
\hline $\begin{array}{l}\text { Docosahexaenoic } \\
\text { acid }\end{array}$ & $\begin{array}{l}\text { Suppressed Procol1a1 and TGF- } \beta 1 \text {, inhibited hepatic inflammation } \\
\text { and oxidative stress markers, including TLR4, TLR9, CD14, MyD88, } \\
\text { and NADPH oxidase subunits }\end{array}$ & $\begin{array}{l}\text { Western diet-induced NASH in } \operatorname{Ldlr}\left(^{-/-}\right) \\
\text {mice }\end{array}$ & {$[114]$} \\
\hline
\end{tabular}

to treat HBV infection [39-41]. Peginterferon $\alpha$ plus ribavirin and direct acting antivirals are used to treat $\mathrm{HCV}$ patients [42]. Long-term use of most virustargeted antiviral therapies may cause drug resistance and side effects, so agents to illuminate drug resistance are needed.

Helioxanthin (Figure 2) was originally isolated from the shrub Taiwania cryptomerioides (Taiwan Shan). Helioxanthin exhibited potent inhibitory activity against HBV replication in HepG 2.2.15 cells and Lamivudine-resistant HBV L536M/M550V double mutant HBV strain [43]. Treatment with helioxanthin suppressed IL-1-induced c-jun transcription and c-jun-mediated DNA-binding activity of AP-1 [44]. In one study, a synthesized derivative of helioxanthin, 8-1, suppressed HBV replication by decreasing the binding of hepatocyte nuclear factors 3 and 4 to the HBV replication machinery [45].
The herbal medicine Scutellaria baicalensis (Huangqin) has been used to reduce inflammation [46]. Wogonin (Figure 2) isolated from Scutellaria baicalensis exhibited potent anti-HBV activity both in vitro and in vivo. Treatment with wogonin suppressed secretion of HBV antigens and reduced HBV DNA levels through inhibition of HBV DNA polymerase activity in the HBVproducing MS-G2 cell line [47].

Matrine and oxymatrine (Figure 2), two alkaloids isolated from the root of the plant Sophora japonica (Kushen), reversed liver fibrosis through downregulation of the TGF- $\beta 1$ pathway [48]. A combination treatment of matrine or oxymatrine with Lamivudine reduced chronic HBV infection-induced liver fibrosis through inhibiting secretion of hepatitis $B$ surface antigen (HBsAg) and hepatitis B e antigen (HBeAg), and replication of HBV DNA [49].

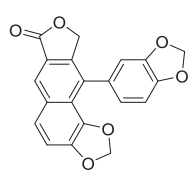

Helioxanthin

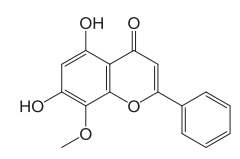

Wogonin

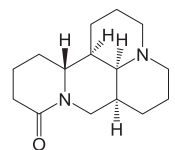

Matrine

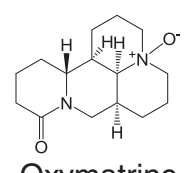

Oxymatrine
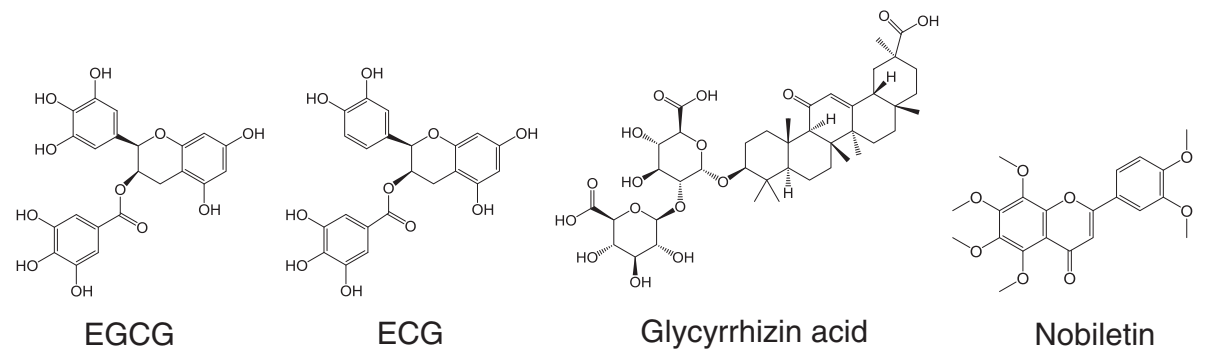

Figure 2 Natural products that inhibit HBV, and HCV replication. 
Polyphenols (-)-epigallocatechin-3-O-gallate (EGCG) and (-)-epicatechin-3-O-gallate (ECG) (Figure 2), from the herbal medicine Rhodiola kirilowii (Regel) Maxim (Xiaye Hongjingtian) exhibited potent inhibitory effect against HCV NS3 serine protease with low cytotoxicity [50]. Polyphenols extracted from green tea also exhibited potent activity against HCV viral entry [51] and replication [52]. In one study, a single oral administration of green tea extract containing 94\% pure EGCG was safe and well-tolerated by all 11 patients with cirrhosis associated with chronic HCV infection [53].

Glycyrrhizin acid (Figure 2), the major component of the root of Glycyrrhiza glabra (Yanggancao), inhibited expression of the HCV full-length viral particle and $\mathrm{HCV}$ core gene synergistically with IFNa [54]. Treatment with glycyrrhizin acid reduced hepatic inflammation through regulation of $\mathrm{CD}^{+} \mathrm{T}$ cell response in a JNK-, ERK-, and PI3K-Akt-dependent manner in mice with liver injury [55]. Glycyrrhizin acid prevented apoptosis and inflammatory infiltrates induced by LPS/GaIN injection through disturbing the binding of HMGB1 protein to the promoter of Gsto1 [56].

Nobiletin ( $3^{\prime}, 4^{\prime}, 5,6,7,8$-hexamethoxyflavone, Figure 2), the active component of Citrus unshiu peel, markedly inhibited HCV absorption in the human lymphoblastic leukemia MOLT-4 cell line [57] and reduced hepatic inflammation through reducing iNOS and DNA-binding activity of nucleus NF- $\mathrm{kB}$ [58].

\section{Anti-inflammatory drugs reduce liver inflammation}

Anti-inflammatory drugs, including corticosteroid, prednisone, and prednisolone, suppress cytokine transcription, thus inhibiting hepatic collagen deposition [59]. These drugs can only effectively and safely treat liver fibrosis in combination with azathioprine [59].

Genistein (Figure 3) is a type of isoflavone first isolated from Hydrocotyle sibthorpioides (Tianhusui) and considered a potent chemopreventive agent with estrogenic activities against breast cancer [60]. Treatment with genistein decreased levels of inflammation mediators, including IL-6, TNF- $\alpha$, and myeloperoxidase, through downregulation of NF- $\mathrm{KB}$ in alcohol- and $\mathrm{CCl}_{4}$-induced liver fibrosis in rats [61].

Salvianic acid A (Figure 3), one of the most widely used natural products in China, is the main active component of Salvia miltiorrhiza (Danshen). In one study, treatment with salvianic acid A inhibited proliferation of HSCs and thus reduced the expression of TGF- $\beta 1$ and collagen I/III. Decreased TGF- $\beta 1$ levels led to inhibition of plasminogen activator, upregulation of the urokinasetype plasminogen activator, and dephosphorylation of Akt and ERK1/2 [62].

Betulin and its oxidized form betulinic acid (Figure 3), a type of triterpene derived from the bark of Betula platyphylla var. japonica, can reverse alcohol-induced cytotoxicity in HepG2 cells [63]. Treatment with betulin and betulinic acid inhibited expression of TNF- $\alpha$, TGF- $\beta 1$,<smiles>O=c1c(-c2ccc(O)cc2)coc2cc(O)cc(O)c12</smiles>

Genistein

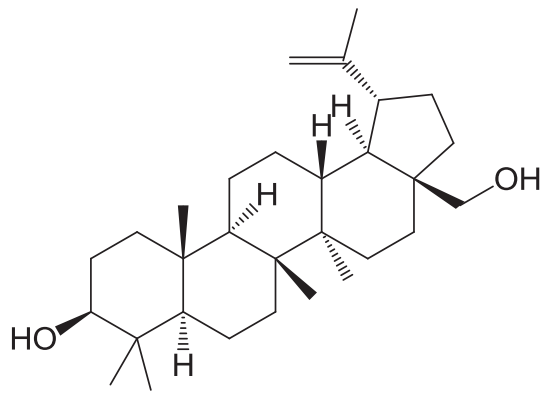

Betulin<smiles>O=C(O)C(O)Cc1ccc(O)c(O)c1</smiles>

Salvianic acid $A$<smiles>C=C(C)[C@H]1CC[C@]2(C(=O)O)CC[C@]3(C)[C@@]4(C)CC[C@H]5C(C)(C)[C@@H](O)CC[C@]5(C)[C@]4(C)CC[C@]3(C)[C@H]12</smiles>

Betulinic acid

Figure 3 Chemical structures of natural products with anti-inflammation activity, including genistein, salvianic acid A, botulin, and betulinic acid. 
tissue inhibitor of metalloproteinase (TIMP)-1, TIMP-2, and activated matrix metalloproteinase (MMP)-2 in alcohol-induced liver fibrosis in vivo [64].

The Chinese herbal formula, Gexia Zhuyu decoction (Gexia Zhuyu Tang; GZT), can attenuate fibrosis and reduce inflammation in the late stage of liver fibrosis [65]. Treatment with GZT improved degeneration and inflammatory necrosis in liver cells, and reduced $\mathrm{CCl}_{4}$ induced collagen deposition in vivo [66].

\section{Cytokine inhibitors attenuate hepatic fibrogenesis}

Research shows that suppression of insulin-like growth factor I improves liver function and reduces liver fibrosis through upregulation of MMPs and downregulation of TIMPs [67]. Elevated levels of IL-17 and its receptors in response to liver damage may also promote the production of IL-1, IL- 6 , TGF- $\alpha$, and collagen I that promote liver fibrosis. Treatment of these kinds of cytokine inhibitors could contribute to inflammation accumulation in the fibrotic liver [68]. The cytokine inhibitors can also decrease IL-22 expression-induced HSC senescence and inhibit hepatic fibrogenesis [69].

The herbal formula Yanggan Wan (YGW) has been shown to be hepatoprotective [70], deactivating HSCs through epigenetic de-repression of PPAR- $\gamma$ in common bile duct-induced cholestatic liver fibrosis mice [71]. The de-repressed PPAR- $\gamma$ was induced by reduced MeCP2 expression and its recruitment to the PPAR- $\gamma$ promoter [71]. Rosmarinic acid and baicalin (Figure 4) from YGW de-repressed PPAR- $\gamma$ through suppression of canonical Wnt signaling in activated HSCs [71]. Baicalin shifts the balance of profibrotic to antifibrotic cytokines and reduces oxidative stress in the fibrotic liver in experimental animal models [72], while romarinic acid can also inhibit proliferation and induce apoptosis of HSCs [73].

Treatment with Yin Chen Hao decoction (Yin Chen Hao Tang; YCHT) can decrease serum IFN- $\gamma$ and IL-12 levels [74]. In the DMN-induced liver fibrotic rat, treatment with YCHT significantly improved the pathological condition through inhibition of $\alpha$-SMA activation and transcription of its target genes [75].

Paeoniflorin (Figure 4), the major bioactive constituent of Moutan cortex (Mudanpi), effectively attenuated $\mathrm{CCl}_{4}$-induced liver fibrosis [76]. In one study, treatment with paeoniflorin reduced the size of egg granuloma, fibrosis scores, IL-13 serum concentration, and hydroxyproline content in the liver of mice infected with $S$. japonicum. Paeoniflorin also showed an inhibitory effect on hepatic fibrogenesis through downregulation of IL-13 expression and abrogation of the IL-13 signaling pathway in activated HSCs [77].

\section{Nuclear receptors that modulate liver fibrogenesis}

FXR is highly expressed in activated HSCs in the fibrotic liver [78]. FXR ligands prevent hepatic fibrogenesis through deactivation of HSCs and decreased ECM expression [78].

Oleanolic acid and ursolic acid (Figure 4) are triterpenoid saponins commonly identified in medicinal plants [79]. Treatment with oleanolic acid inhibited the production of bile acids through blocking the interactions between FXR and its coactivator SRC-3 and endogenous ligand chenodeoxycholic acid [80]. Oleanolic acid blocked the binding of endogenous ligand chenodeoxycholic acid to FXR, suppressing expression of FXR-targeted bile salt export protein. There is evidence

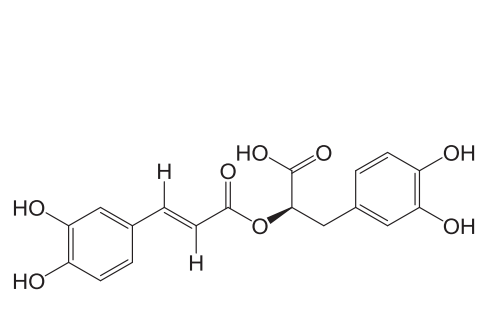

Rosmarinic acid

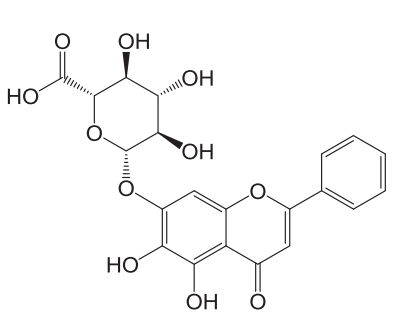

Baicalin

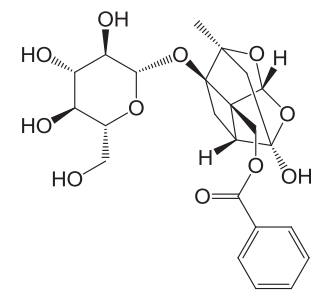

Paeoniflorin

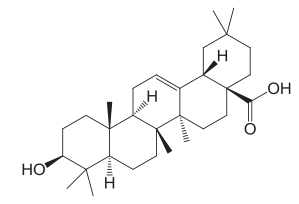

Oleanolic acid

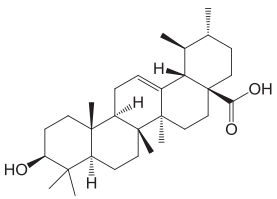

Ursolic acid

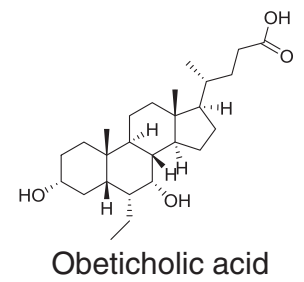

Figure 4 Cytokine inhibitors, including ursolic acid, paeniflorin, baicalin, and rosmarinic acid, and nuclear receptor modulators, including oleanolic acid, ursolic acid, and obeticholic acid as nuclear receptor modulators. 
that oleanolic acid and ursolic acid reduce hepatic free radical content through increasing hepatic transcription of Nrf2 target genes, including $\mathrm{NAD}(\mathrm{P}) \mathrm{H}$ :quinone oxidoreductase 1, glutamate-cysteine ligase, catalytic subunit, heme oxygenase- 1 , and Nrf2 itself $[81,82]$.

\section{Antioxidants as hepatoprotective agents in liver fibrosis management}

Silymarin, the extract of the milk thistle or Silybum marianum (Shuifeiji), consists of four flavonolignan isomers: silybin, isosilybin, silydianin, and silychristin (Figure 5). Silymarin has been widely used as a single-herb remedy for treating liver diseases. Silymarin treatment protects further liver damage by its antioxidant and antiinflammatory activities $[83,84]$. Silybinin, also called silybin, exhibited hepatoprotective and antifibrogenic effects by inhibiting TGF- $\beta 1$-induced collagen secretion and oxidase stress both in vivo and in vitro [85].

Acanthus ilicifolius alkaloid A (4-hydroxy-2(3H)benzoxazolone) was first isolated from Acanthus ilicifolius (Juechuangle) [86]. Acanthus ilicifolius alkaloid A and its acyl derivatives have been used as antioxidant, antiinflammatory, and analgesic agents [87]. This group of analogs inhibits progression of $\mathrm{CCl}_{4}$-induced liver fibrosis by reducing lipid peroxidation and oxidative stress [88].

Curcumin (Figure 5), the main active component of turmeric, protects the $\mathrm{CCl}_{4}$-induced fibrotic liver through its antioxidant activity $[89,90]$. Treatment with curcumin suppressed multiple pro-angiogenic factors that modulate cannabinoid receptors and inhibited ECM expression, thus decreasing collagen deposition $[89,91]$. In one study, treatment with curcumin also increased serum MMP-13 and glutathione levels, thus reversing fibrosis in $\mathrm{CCl}_{4}$-induced liver fibrosis in rats [91].

$\beta$-caryophyllene (Figure 5) is a natural sesquiterpene identified in the essential oil of numerous plants and fruits [92]. In one study, $\beta$-caryophyllene exhibited high scavenging activity against hydroxyl radicals and superoxide anions, which inhibited lipid peroxidation and suppressed expression of Colla1 and TIMP-1 in $\mathrm{CCl}_{4-}$ induced mouse liver fibrosis [93].

\section{Modulation of the balance between EMT and MET to treat liver fibrosis}

Treatment with Diwu Yanggan (DWYG) significantly decreased the hepatic hydroxyproline content and degree of $\mathrm{CCl}_{4}$-induced liver fibrosis in rats [94] and stimulated MET in the fibrotic liver through inhibition of the TGFB1/BMP-7 signaling pathway [94].

Research shows that Fuzheng Huayu (FZHY) formula reverses EMT in the fibrotic kidney through suppression of $\alpha$-SMA, TGF- $\beta 1$, and nuclear translocation of SMAD3 [95]. In one study using the renal fibrosis model, treatment with salvianolic acid B from Danshen abrogated EMT by counteracting the TGF- $\beta 1$ signaling pathway [96].

\section{Herbal medicines and natural products in clinical trials}

FZHY formula to treat liver fibrosis [97] has completed phase II clinical trials approved by the FDA $[98,99]$. FZHY tablet consists of $R$. miltiorrhizae (Danshen), fermented Mycelium (Chongcao), Semen persicae (Taoren), Fructus schisandrae (Wuweizi), Chinensis pollen pini (Songhuafen), and Gynostemma pentaphyllammak (Jiaogulan) [100]. Administration of FZHY tablet

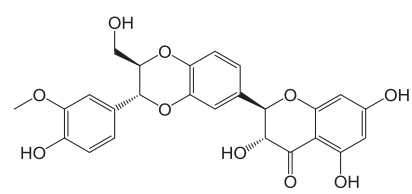

Silybin

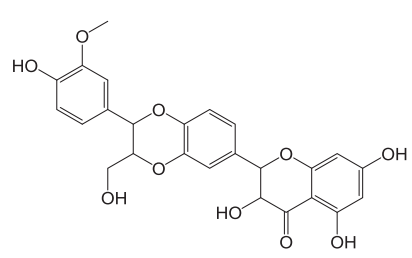

Isosilybin

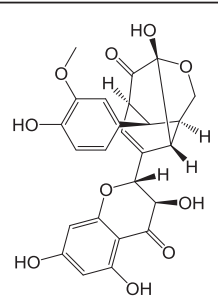

Silydianin

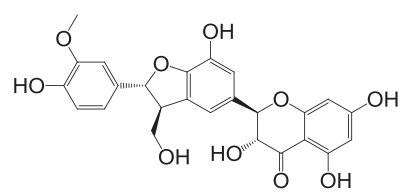

Silychristin

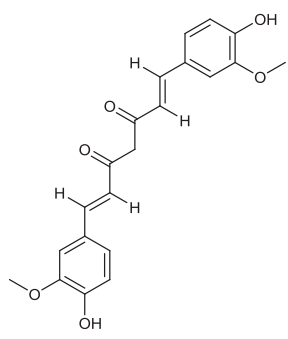

Curcumin

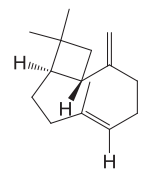

$\beta$-Caryophyllene

Figure 5 Chemical structures of antioxidative agents, including silybin, isosilybin, silydianin, silychristin, curucmin, and $\beta$-caryophyllene. 
improved liver function, serum fibrotic parameters and cirrhosis; decreased portal pressure; and regulated immune function and amino acid balance in 216 liver fibrosis patients with chronic HBV in a multicenter study [98]. Patients with posthepatitic cirrhosis showed improved liver function, decreased fibrotic score, prolonged 2-year survival, and reduced symptom scores after administration of FZHY tablet [101]. A multicenter, double-blind, randomized, and controlled clinical trial confirmed the efficacy of FZHY tablet, which decreased serum hyaluronic acid levels in patients with chronic HBV caused by cirrhosis [102]. Supplemental administration of FZHY tablet with nucleos(t)ide analogs to patients with chronic HBV also decreased serum fibrosis markers, including hyaluronic acid, laminin, amino-terminal propeptide of type III procollagen, and IV collagen [103].

FZHY tablet exhibits multiple mechanisms of action against liver fibrosis/cirrhosis [101]; its known active ingredients include salvianoic acid B and adenosine [102]. FZHY tablet exhibits antifibrotic activity by inducing apoptosis in HSC-T6 cells through p38 and SAPK/ JNK pathways $[99,104]$, and inhibits liver fibrosis through decreasing transcription of TIMP-1, PDGF-B, and PDGF receptor $\beta 1$ in vivo [99]. A study of chronic HBV infection-induced fibrosis and cirrhosis patients showed that its therapeutic efficacy is closely related to the GA plus AA polymorphism of $\mathrm{CYP}_{1} \mathrm{~A}_{2}$ [105].

Fufang Biejia Ruangan (FFBJRG) pill, consisting of Carapax Trionycis (Biejia), Radix Paeoniae Rubra (Chishao), Radix Angelicae Sinensis (Danggui), Codonopsis Pilosula (Dangshen), and Radix Astragali (Huangqi), is the first anti-liver fibrosis drug approved by the China Food and Drug Administration [106]. FFBJRG pill inhibited hepatic fibrosis in vitro and in vivo by inhibiting TGF- $\beta 1 /$ SMAD pathway transduction [107] and is currently in phase IV clinical trials in the United States for the treatment of chronic HBV infection-associated liver fibrosis [108].

Treatment with silybin-phospholipids and vitamin $\mathrm{E}$ complex (SPV complex) significantly reduced liver fibrosis scores and downregulated fibrosis markers in fatty liver-associated $\mathrm{HCV}$-positive patients in 11 Italian and 2 Romanian centers [109]. The SPV complex is currently in phase III clinical trials in the US for the treatment of liver fibrosis. The anti-liver fibrosis effect of the SPV complex is mainly due to deactivation of HSCs and downregulation of TGF- $\beta 1$ and TNF- $\alpha$ expression [110].

Obeticholic acid (Figure 6) is a semisynthetic derivative of bile acid and an FXR agonist. Treatment with obeticholic acid inhibits synthesis and accumulation of bile acid in the liver [111]. Patients with type 2 diabetes and non-alcoholic fatty liver disease showed significantly reduced markers of liver inflammation and fibrosis after administration of $25 \mathrm{mg}$ obeticholic acid for 6 weeks in a phase II clinical trial in the US [112].

Docosahexaenoic acid (DHA, Figure 6), an omega-3 fatty acid, was originally isolated from maternal milk or fish oil. DHA is in phase II clinical trials for the treatment of liver fibrosis in the US [113]. Treatment with DHA inhibited hepatic fibrogenesis through suppression of Procol $1 \alpha 1$ and TGF- $\beta 1$ and inhibited hepatic inflammation and oxidative stress markers, including TLR4, TLR9, CD14, MyD88, and different NADPH oxidase subunits [114].

\section{Conclusion}

Despite cumulative evidence of success in treating liver fibrosis, in vivo results are insufficient to confirm the clinical efficacy of natural products and herbal medicines for liver fibrosis. The identification of resources and the molecular mechanisms of action of these substances remain extremely challenging.

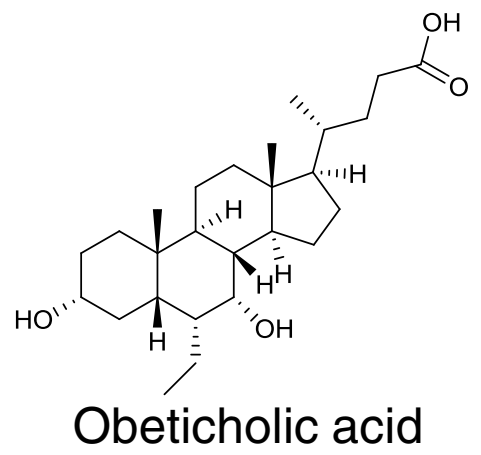

Figure 6 Chemical structures of oleanolic acid, and docosahexaenoic acid.<smiles>CC/C=C\C/C=C\C/C=C\C/C=C\C/C=C\C/C=C\CCC(=O)O</smiles>

Docosahexaenoic acid 


\section{Abbreviations}

$\mathrm{CCl}_{4}$ : Carbon tetrachloride; ECM: Extracellular matrix; EMT: Epithelialmesenchymal transition; FOX: Forkhead box; FXR: Farnesoid X receptor; HBV: Hepatitis B virus; HCV: Hepatitis C virus; HSC: Hepatic stellate cell; IFN: Interferon; IL: Interleukin; IRAK: Interleukin-1 receptor-associated kinase; LPS: Lipopolysaccharide; MET: Mesenchymal-epitelial transition; MMP: Matrix metalloproteinase; MyD88: Myeloid differentiation primary response gene 88; Nrf2: Nuclear factor (erythroid-derived 2)-like 2; PDGF: Platelet-derived growth factor; PI3K: Phosphatidyl inositol 3-kinase; PPAR: Peroxisome proliferator-activated receptor; ROS: Reactive oxygen species; SHP: Small heterodimer partner mRNA; $a-S M A$ : $a-$ smooth muscle actin; TAK1: TGF- $\beta$ activated kinase 1; TIMP: Tissue inhibitor of metalloproteinase; TLR: Toll-like receptor; TNF: Tumor necrosis factor; TRAF6: Tumor necrosis factor receptor-associated factor-6; VDR: Vitamin D receptor.

\section{Competing interests}

The authors declare that they have no competing interests.

\section{Authors' contributions}

YW and YTW designed the study. SRC, XPC and JJ searched and analyzed the references. SRC wrote the manuscript. YW, YTW and SRC revised the manuscript. All authors read and approved the final manuscript to be published.

\section{Acknowledgments}

This work was partially supported by the Macao Science and Technology Development Fund 074/2012/A3 to YTW, Research Fund of the University of Macao SRG2013-00036-ICMS-QRCM, MYRG2014-00161-ICMS-QRCM, and Macao Science and Technology Development Fund 125/2013/A to YW.

\section{Received: 12 May 2014 Accepted: 1 April 2015}

\section{Published online: 15 April 2015}

\section{References}

1. Hernandez-Gea V, Friedman SL. Pathogenesis of liver fibrosis. Annu Rev Pathol. 2011;6:425.

2. Popov Y, Schuppan D. Targeting liver fibrosis: strategies for development and validation of antifibrotic therapies. Hepatology. 2009;50(4):1294.

3. Lee UE, Friedman SL. Mechanisms of hepatic fibrogenesis. Best Pract Res Clin Gastroenterol. 2011;25(2):195.

4. Brenner DA. Molecular pathogenesis of liver fibrosis. Trans Am Clin Climatol Assoc. 2009;120:361.

5. Bataller R, Brenner DA. Liver fibrosis. J Clin Invest. 2005:115(2):209.

6. Pellicoro A, Ramachandran P, Iredale JP, Fallowfield JA. Liver fibrosis and repair: immune regulation of wound healing in a solid organ. Nat Rev Immunol. 2014;14(3):181.

7. Kisseleva T, Uchinami H, Feirt N, Quintana-Bustamante O, Segovia JC, Schwabe $\mathrm{RF}$, et al. Bone marrow-derived fibrocytes participate in pathogenesis of liver fibrosis. J Hepatol. 2006:45(3):429.

8. Yan K, Deng X, Zhai X, Zhou M, Jia X, Luo L, et al. p38 mitogen-activated protein kinase and liver $X$ receptor-alpha mediate the leptin effect on sterol regulatory element binding protein-1c expression in hepatic stellate cells. Mol Med. 2012;18:10

9. Ren ZP, Sun LP, Xia YC, Tong QX. Effect of the protease inhibitor MG132 on the transforming growth factor-beta/Smad signaling pathway in HSC-T6 cells. J Huazhong Univ Sci Technolog Med Sci. 2013:33(4):501.

10. Woodhoo A, Iruarrizaga-Lejarreta M, Beraza N, Garcia-Rodriguez JL, Embade N, Fernandez-Ramos D, et al. Human antigen R contributes to hepatic stellate cell activation and liver fibrosis. Hepatology. 2012;56(5):1870.

11. Horbelt D, Denkis A, Knaus P. A portrait of Transforming Growth Factor beta superfamily signalling: Background matters. Int J Biochem Cell Biol. 2012;44(3):469.

12. Borthwick LA, Gardner A, De Soyza A, Mann DA, Fisher AJ. Transforming Growth Factor-beta1 (TGF-beta1) Driven Epithelial to Mesenchymal Transition (EMT) is Accentuated by Tumour Necrosis Factor alpha (TNFalpha) via Crosstalk Between the SMAD and NF-kappaB Pathways. Cancer Microenviron. 2012:5(1):45.

13. Yang J, Zheng J, Wu L, Shi M, Zhang H, Wang X, et al. NDRG2 ameliorates hepatic fibrosis by inhibiting the TGF-beta1/Smad pathway and altering the MMP2/TIMP2 ratio in rats. PLoS One. 2011;6(11), e27710.
14. Kulkarni AA, Thatcher TH, Olsen KC, Maggirwar SB, Phipps RP, Sime PJ. PPAR-gamma ligands repress TGFbeta-induced myofibroblast differentiation by targeting the PI3K/Akt pathway: implications for therapy of fibrosis. PLoS One. 2011;6(1), e15909.

15. Zhu Q, Zou L, Jagavelu K, Simonetto DA, Huebert RC, Jiang Z-D, et al. Intestinal decontamination inhibits TLR4 dependent fibronectin-mediated cross-talk between stellate cells and endothelial cells in liver fibrosis in mice. J Hepatol. 2012:56(4):893.

16. Jagavelu K, Routray C, Shergill U, O'Hara SP, Faubion W, Shah VH. Endothelial cell toll-like receptor 4 regulates fibrosis-associated angiogenesis in the liver. Hepatology. 2010;52(2):590.

17. da Silva Correia J, Soldau K, Christen U, Tobias PS, Ulevitch RJ. Lipopolysaccharide is in close proximity to each of the proteins in its membrane receptor complex. transfer from CD14 to TLR4 and MD-2. J Biol Chem. 2001:276(24):21129.

18. Luedde T, Schwabe RF. NF-kappaB in the liver-linking injury, fibrosis and hepatocellular carcinoma. Nat Rev Gastroenterol Hepatol. 2011:8(2):108.

19. Tacke F, Luedde T, Trautwein C. Inflammatory pathways in liver homeostasis and liver injury. Clin Rev Allergy Immunol. 2009;36(1):4.

20. Bookout AL, Jeong Y, Downes M, Yu RT, Evans RM, Mangelsdorf DJ. Anatomical profiling of nuclear receptor expression reveals a hierarchical transcriptional network. Cell. 2006;126(4):789.

21. Forman BM, Goode E, Chen J, Oro AE, Bradley DJ, Perlmann T, et al. Identification of a nuclear receptor that is activated by farnesol metabolites. Cell. 1995:81(5):687.

22. Chawla A, Saez E, Evans RM. "Don't know much bile-ology". Cell. 2000;103(1):1.

23. Hoeke MO, Heegsma J, Hoekstra M, Moshage H, Faber KN. Human FXR regulates SHP expression through direct binding to an $\mathrm{LRH}-1$ binding site, independent of an IR-1 and LRH-1. PLoS One. 2014;9(2), e88011.

24. Fiorucci S, Rizzo G, Antonelli E, Renga B, Mencarelli A, Riccardi L, et al. A farnesoid $x$ receptor-small heterodimer partner regulatory cascade modulates tissue metalloproteinase inhibitor-1 and matrix metalloprotease expression in hepatic stellate cells and promotes resolution of liver fibrosis. J Pharmacol Exp Ther. 2005:314(2):584

25. Ding N, Yu RT, Subramaniam N, Sherman MH, Wilson C, Rao R, et al. A vitamin $D$ receptor/SMAD genomic circuit gates hepatic fibrotic response. Cell. 2013;153(3):601.

26. Fowell AJ, Collins JE, Duncombe DR, Pickering JA, Rosenberg WM, Benyon RC. Silencing tissue inhibitors of metalloproteinases (TIMPS) with short interfering RNA reveals a role for TIMP-1 in hepatic stellate cell proliferation. Biochem Biophys Res Commun. 2011;407(2):277.

27. Xiao Y, Wang J, Chen Y, Zhou K, Wen J, Wang Y, et al. Up-regulation of miR-200b in biliary atresia patients accelerates proliferation and migration of hepatic stallate cells by activating PI3K/Akt signaling. Cell Signal. 2014;26(5):925.

28. M Zardi E, Navarini L, Sambataro G, Piccinni P, M Sambataro F, Spina C, et al. Hepatic PPARs: their role in liver physiology, fibrosis and treatment. Curr Med Chem. 2013;20(27):3370.

29. Hatanaka H, Koizumi N, Okumura N, Kay EP, Mizuhara E, Hamuro J, et al. Epithelial-mesenchymal transition-like phenotypic changes of retinal pigment epithelium induced by TGF-beta are prevented by PPAR-gamma agonists. Invest Ophthalmol Vis Sci. 2012:53(11):6955.

30. Chen S, Zou L, Li L, Wu T. The protective effect of glycyrrhetinic acid on carbon tetrachloride-induced chronic liver fibrosis in mice via upregulation of Nrf2. PLoS One. 2013;8(1), e53662.

31. Halliwell B. Free radicals and antioxidants - quo vadis? Trends Pharmacol Sci. 2011:32(3):125

32. Yang L, Roh YS, Song J, Zhang B, Liu C, Loomba R, et al. Transforming growth factor beta signaling in hepatocytes participates in steatohepatitis through regulation of cell death and lipid metabolism in mice. Hepatology. 2014;59(2):483.

33. Acloque $H$, Adams MS, Fishwick K, Bronner-Fraser M, Nieto MA. Epithelialmesenchymal transitions: the importance of changing cell state in development and disease. J Clin Invest. 2009:119(6):1438.

34. Kang M, Choi S, Jeong SJ, Lee SA, Kwak TK, Kim H, et al. Cross-talk between TGFbeta1 and EGFR signalling pathways induces TM4SF5 expression and epithelial-mesenchymal transition. Biochem J. 2012;443(3):691.

35. Troeger JS, Mederacke I, Gwak GY, Dapito DH, Mu X, Hsu CC, et al. Deactivation of hepatic stellate cells during liver fibrosis resolution in mice Gastroenterology. 2012;143(4):1073.

36. Kong D, Zhang F, Zhang Z, Lu Y, Zheng S. Clearance of activated stellate cells for hepatic fibrosis regression: molecular basis and translational potential. Biomed Pharmacother. 2013;67(3):246. 
37. Nakagawa H, Hikiba Y, Hirata Y, Font-Burgada J, Sakamoto K, Hayakawa Y, et al. Loss of liver E-cadherin induces sclerosing cholangitis and promotes carcinogenesis. Proc Natl Acad Sci U S A. 2014;111(3):1090.

38. Zimmermann HW, Tacke F. Modification of chemokine pathways and immune cell infiltration as a novel therapeutic approach in liver inflammation and fibrosis. Inflamm Allergy Drug Targets. 2011;10(6):509.

39. Fung J, Lai CL, Yuen J, Cheng C, Wu R, Wong DK, et al. Randomized trial of lamivudine versus entecavir in entecavir-treated patients with undetectable hepatitis B virus DNA: outcome at 2 Years. Hepatology. 2011;53(4):1148.

40. Wong W, Wong GL, Yiu KK, Chim AM, Chu SH, Chan HY, et al. Entecavir treatment in patients with severe acute exacerbation of chronic hepatitis B. J Hepatol. 2011;54(2):236.

41. Wong DK, Kopaniszen M, Omagari K, Tanaka Y, Fong DY, Seto WK, et al. Effect of hepatitis B virus reverse transcriptase variations on entecavir treatment response. J Infect Dis. 2014;210(5):701.

42. Rehermann B. Pathogenesis of chronic viral hepatitis: differential roles of $T$ cells and NK cells. Nat Med. 2013;19(7):859.

43. Li Y, Fu L, Yeo H, Zhu JL, Chou CK, Kou YH, et al. Inhibition of hepatitis B virus gene expression and replication by helioxanthin and its derivative. Antivir Chem Chemother. 2005;16(3):193.

44. Tseng PC, Hsu HC, Janmanchi D, Lin CH, Kuo YH, Chou CK, et al. Helioxanthin inhibits interleukin-1 beta-induced MIP-1 beta production by reduction of $c$-jun expression and binding of the c-jun/CREB1 complex to the AP-1/CRE site of the MIP-1 beta promoter in Huh7 cells. Biochem Pharmacol. 2008;76(9):1121.

45. Ying C, Li Y, Leung CH, Robek MD, Cheng YC. Unique antiviral mechanism discovered in anti-hepatitis $B$ virus research with a natural product analogue. Proc Natl Acad Sci U S A. 2007;104(20):8526.

46. Guo Q, Zhao L, You Q, Yang Y, Gu H, Song G, et al. Anti-hepatitis B virus activity of wogonin in vitro and in vivo. Antivir Res. 2007;74(1):16.

47. Huang RL, Chen CC, Huang HL, Chang CG, Chen CF, Chang C, et al. Antihepatitis $B$ virus effects of wogonin isolated from Scutellaria baicalensis. Planta medica. 2000;66(8):694

48. Zhang JP, Zhang M, Zhou JP, Liu FT, Zhou B, Xie WF, et al. Antifibrotic effects of matrine on in vitro and in vivo models of liver fibrosis in rats. Acta pharmacologica Sinica. 2001;22(2):183

49. Ma ZJ, Li Q, Wang JB, Zhao YL, Zhong YW, Bai YF, et al. Combining Oxymatrine or Matrine with Lamivudine Increased Its Antireplication Effect against the Hepatitis B Virus In Vitro. Evid based Complement Altern Med. 2013;2013:186573.

50. Zuo G, Li Z, Chen L, Xu X. Activity of compounds from Chinese herbal medicine Rhodiola kirilowii (Regel) Maxim against HCV NS3 serine protease Antivir Res. 2007:76(1):86

51. Ciesek S, von Hahn T, Colpitts CC, Schang LM, Friesland M, Steinmann J, et al. The green tea polyphenol, epigallocatechin-3-gallate, inhibits hepatitis C virus entry. Hepatology. 2011;54(6):1947.

52. Fukazawa H, Suzuki T, Wakita T, Murakami Y. A cell-based, microplate colorimetric screen identifies 7,8-benzoflavone and green tea gallate catechins as inhibitors of the hepatitis C virus. Biol Pharm Bull. 2012;35(8):1320

53. Halegoua-De Marzio D, Kraft WK, Daskalakis C, Ying X, Hawke RL, Navarro VJ. Limited sampling estimates of epigallocatechin gallate exposures in cirrhotic and noncirrhotic patients with hepatitis $C$ after single oral doses of green tea extract. Clin Ther. 2012;34(12):2279.

54. Ashfaq UA, Masoud MS, Nawaz Z, Riazuddin S. Glycyrrhizin as antiviral agent against Hepatitis C Virus. J Transl Med. 2011;9:112.

55. Tu CT, Li J, Wang FP, Li L, Wang JY, Jiang W. Glycyrrhizin regulates CD4 + T cell response during liver fibrogenesis via JNK, ERK and PI3KJAKT pathway. Int Immunopharmacol. 2012;14(4):410.

56. Kuroda N, Inoue K, Ikeda T, Hara Y, Wake K, Sato T. Apoptotic Response through a High Mobility Box 1 Protein-Dependent Mechanism in LPS/GalNInduced Mouse Liver Failure and Glycyrrhizin-Mediated Inhibition. PLoS One. 2014;9(4), e92884

57. Suzuki M, Sasaki K, Yoshizaki F, Oguchi K, Fujisawa M, Cyong JC. Antihepatitis $C$ virus effect of citrus unshiu peel and its active ingredient nobiletin. Am J Chin Med. 2005;33(1):87.

58. Yoshigai E, Machida T, Okuyama T, Mori M, Murase H, Yamanishi R, et al. Citrus nobiletin suppresses inducible nitric oxide synthase gene expression in interleukin-1 beta-treated hepatocytes. Biochem Biophys Res Commun. 2013;439(1):54

59. Czaja AJ. Drug choices in autoimmune hepatitis: part A-Steroids. Expert Rev Gastroenterol Hepatol. 2012;6(5):603.
60. Ullah MF, Ahmad A, Zubair H, Khan HY, Wang Z, Sarkar FH, et al. Soy isoflavone genistein induces cell death in breast cancer cells through mobilization of endogenous copper ions and generation of reactive oxygen species. Mol Nutr Food Res. 2011;55(4):553.

61. Huang Q, Huang R, Zhang S, Lin J, Wei L, He M, et al. Protective effect of genistein isolated from Hydrocotyle sibthorpioides on hepatic injury and fibrosis induced by chronic alcohol in rats. Toxicol Lett. 2013;217(2):102.

62. Zhang L, Wu T, Chen JM, Yang LL, Song HY, Ji G. Danshensu inhibits acetaldehyde-induced proliferation and activation of hepatic stellate cell-T6. Zhong Xi Yi Jie He Xue Bao. 2012;10(10):1155.

63. Szuster-Ciesielska A, Kandefer-Szerszen M. Protective effects of betulin and betulinic acid against ethanol-induced cytotoxicity in HepG2 cells. Pharmacol Rep. 2005:57(5):588.

64. Szuster-Ciesielska A, Plewka K, Daniluk J, Kandefer-Szerszen M. Betulin and betulinic acid attenuate ethanol-induced liver stellate cell activation by inhibiting reactive oxygen species (ROS), cytokine (TNF-alpha, TGF-beta) production and by influencing intracellular signaling. Toxicology. 2011;280(3):152.

65. Chen JY, Chen HL, Cheng JC, Lin HJ, Tung YT, Lin CF, et al. A Chinese herbal medicine, Gexia-Zhuyu Tang (GZT), prevents dimethylnitrosamine-induced liver fibrosis through inhibition of hepatic stellate cells proliferation. J Ethnopharmacol. 2012;142(3):811.

66. Zhao Z, Yu H, Peng Y, Ren H, Tao Y, Wang Z, et al. Comparison of effect of formulas clearing away heat and promoting blood circulation on prevention and treatment of liver fibrosis in CCl4 mice. Zhongguo Zhong Yao Za Zhi. 2012;37(12):1804.

67. Sobrevals L, Rodriguez C, Romero-Trevejo JL, Gondi G, Monreal I, Paneda A et al. Insulin-like growth factor I gene transfer to cirrhotic liver induces fibrolysis and reduces fibrogenesis leading to cirrhosis reversion in rats. Hepatology. 2010;51(3):912.

68. Meng F, Wang K, Aoyama T, Grivennikov SI, Paik Y, Scholten D, et al. Interleukin-17 signaling in inflammatory, Kupffer cells, and hepatic stellate cells exacerbates liver fibrosis in mice. Gastroenterology. 2012;143(3):765

69. Kong X, Feng D, Wang H, Hong F, Bertola A, Wang FS, et al. Interleukin-22 induces hepatic stellate cell senescence and restricts liver fibrosis in mice. Hepatology. 2012;56(3):1150.

70. Yang MD, Deng QG, Chen S, Xiong S, Koop D, Tsukamoto $\mathrm{H}$. Hepatoprotective mechanisms of Yan-gan-wan. Hepatol Res. 2005;32(4):202.

71. Yang MD, Chiang YM, Higashiyama R, Asahina K, Mann DA, Mann J, et al Rosmarinic acid and baicalin epigenetically derepress peroxisomal proliferator-activated receptor gamma in hepatic stellate cells for their antifibrotic effect. Hepatology. 2012;55(4):1271.

72. Sun $\mathrm{H}$, Che QM, Zhao X, Pu XP. Antifibrotic effects of chronic baicalein administration in a CCl4 liver fibrosis model in rats. Eur J Pharmacol. 2010;631(1-3):53.

73. Zhang JJ, Wang YL, Feng XB, Song XD, Liu WB. Rosmarinic acid inhibits proliferation and induces apoptosis of hepatic stellate cells. Biol Pharm Bull. 2011;34(3):343.

74. Wang $X$, Sun $H$, Zhang A, Jiao G, Sun W, Yuan Y. Pharmacokinetics screening for multi-components absorbed in the rat plasma after oral administration traditional Chinese medicine formula Yin-Chen-Hao-Tang by ultra performance liquid chromatography-electrospray ionization/ quadrupole-time-of-flight mass spectrometry combined with pattern recognition methods. Analyst. 2011;136(23):5068

75. Mase A, Makino B, Tsuchiya N, Yamamoto M, Kase Y, Takeda S, et al. Active ingredients of traditional Japanese (kampo) medicine, inchinkoto, in murine concanavalin A-induced hepatitis. J Ethnopharmacol. 2010;127(3):742

76. Liu C, Sun M, Wang L, Wang G, Chen G, Liu C, et al. Effects of Yinchenhao Tang and related decoctions on DMN-induced cirrhosis/fibrosis in rats. Chin Med. 2008:3:1

77. Li R, Guo W, Fu Z, Ding G, Zou Y, Wang Z. Hepatoprotective action of Radix Paeoniae Rubra aqueous extract against CCl4-induced hepatic damage. Molecules. 2011;16(10):8684.

78. Li X, Shen J, Zhong Z, Peng J, Wen H, Li J, et al. Paeoniflorin ameliorates schistosomiasis liver fibrosis through regulating $\mathrm{LL}-13$ and its signalling molecules in mice. Parasitology. 2010;137(8):1213.

79. Roderburg C, Urban GW, Bettermann K, Vucur M, Zimmermann H, Schmidt $\mathrm{S}$, et al. Micro-RNA profiling reveals a role for miR-29 in human and murine liver fibrosis. Hepatology. 2011;53(1):209. 
80. Shyu MH, Kao TC, Yen GC. Oleanolic acid and ursolic acid induce apoptosis in $\mathrm{HuH7}$ human hepatocellular carcinoma cells through a mitochondrialdependent pathway and downregulation of XIAP. J Agric Food Chem. 2010;58(10):6110.

81. Liu W, Wong C. Oleanolic acid is a selective farnesoid $\mathrm{X}$ receptor modulator. Phytother Res. 2010;24(3):369.

82. Reisman SA, Aleksunes LM, Klaassen CD. Oleanolic acid activates Nrf2 and protects from acetaminophen hepatotoxicity via Nrf2-dependent and Nrf2-independent processes. Biochem Pharmacol. 2009;77(7):1273.

83. Shaker E, Mahmoud H, Mnaa S. Silymarin, the antioxidant component and Silybum marianum extracts prevent liver damage. Food Chem Toxicol. 2010;48(3):803

84. Pradhan SC, Girish C. Hepatoprotective herbal drug, silymarin from experimental pharmacology to clinical medicine. Indian J Med Res. 2006;124(5):491.

85. Tzeng J, Chen MF, Chung HH, Cheng JT. Silymarin decreases connective tissue growth factor to improve liver fibrosis in rats treated with carbon tetrachloride. Phytother Res. 2013;27(7):1023.

86. Ali SO, Darwish HA, Ismail NA. Modulatory effects of curcumin, silybinphytosome and alpha-R-lipoic acid against thioacetamide-induced liver cirrhosis in rats. Chem Biol Interact. 2014;216:26.

87. Liu L, Fan H, Qi P, Mei Y, Zhou L, Cai L, et al. Synthesis and hepatoprotective properties of alkaloid A and its derivatives. Exp Ther Med. 2013;6(3):796.

88. Charlier C, Michaux C. Dual inhibition of cyclooxygenase-2 (COX-2) and 5-lipoxygenase (5-LOX) as a new strategy to provide safer non-steroidal anti-inflammatory drugs. Eur J Med Chem. 2003;38(7-8):645.

89. Vera-Ramirez L, Pérez-Lopez P, Varela-Lopez A, Ramirez-Tortosa M, Battino M, Quiles JL. Curcumin and liver disease. BioFactors. 2013;39(1):88.

90. Gao S, Duan X, Wang X, Dong D, Liu D, Li X, et al. Curcumin attenuates arsenic-induced hepatic injuries and oxidative stress in experimental mice through activation of Nrf2 pathway, promotion of arsenic methylation and urinary excretion. Food Chem Toxicol. 2013;59:739.

91. Zhang Z, Guo Y, Zhang S, Zhang Y, Wang Y, Ni W, et al. Curcumin modulates cannabinoid receptors in liver fibrosis in vivo and inhibits extracellular matrix expression in hepatic stellate cells by suppressing cannabinoid receptor type-1 in vitro. Eur J Pharmacol. 2013;721(1):133.

92. Horvath B, Mukhopadhyay P, Kechrid M, Patel V, Tanchian G, Wink DA, et a. beta-Caryophyllene ameliorates cisplatin-induced nephrotoxicity in a cannabinoid 2 receptor-dependent manner. Free Radic Biol Med. 2012;52(8):1325.

93. Calleja MA, Vieites JM, Montero-Meterdez T, Torres MI, Faus MJ, Gil A, et al. The antioxidant effect of beta-caryophyllene protects rat liver from carbon tetrachloride-induced fibrosis by inhibiting hepatic stellate cell activation. Br J Nutr. 2013;109(3):394.

94. Shen X, Cheng S, Peng Y, Song H, Li H. Attenuation of early liver fibrosis by herbal compound "Diwu Yanggan" through modulating the balance between epithelial-to-mesenchymal transition and mesenchymal-to-epithelial transition. BMC Complement Altern Med. 2014;14:418.

95. Wang QL, Yuan JL, Tao YY, Zhang Y, Liu P, Liu CH. Fuzheng Huayu recipe and vitamin $E$ reverse renal interstitial fibrosis through counteracting TGF-beta1-induced epithelial-to-mesenchymal transition. J Ethnopharmacol. 2010;127(3):631.

96. Wang QL, Tao YY, Yuan JL, Shen L, Liu CH. Salvianolic acid B prevents epithelial-to-mesenchymal transition through the TGF-beta1 signal transduction pathway in vivo and in vitro. BMC Cell Biol. 2010;11:31.

97. Liu C, Liu P, Liu CH, Zhu XQ, Ji G. Effects of Fuzhenghuayu decoction on collagen synthesis of cultured hepatic stellate cells, hepatocytes and fibroblasts in rats. World J Gastroenterol. 1998;4(6):548.

98. Liu P, Hu YY, Liu C, Xu LM, Liu CH, Sun KW, et al. Multicenter clinical study on Fuzhenghuayu capsule against liver fibrosis due to chronic hepatitis B. World J Gastroenterol. 2005;11(19):2892.

99. Liu P. Fuzheng huayu capsule in the treatment of liver fibrosis: clinical evidence and mechanism of action. Chin J Integr Med. 2012;18(5):398.

100. Cheung KF, Ye DW, Yang ZF, Lu L, Liu CH, Wang XL, et al. Therapeutic efficacy of Traditional Chinese Medicine 319 recipe on hepatic fibrosis induced by carbon tetrachloride in rats. J Ethnopharmacol. 2009;124(1):142.

101. Deng X, Liang J, Liu ZW, Wu FS, Li X. Treatment of posthepatitic cirrhosis by Fuzheng Huayu Tablet for reinforcing qi and resolving stasis. Chin J Integr Med. 2013;19(4):289.

102. Song YN, Sun JJ, Lu YY, Xu LM, Gao YQ, Zhang W, et al. Therapeutic efficacy of fuzheng-huayu tablet based traditional chinese medicine syndrome differentiation on hepatitis-B-caused cirrhosis: a multicenter double-blind randomized controlled trail. Evid based Complement Altern Med. 2013;2013:709305.
103. Tian YL, Zhu XY, Yin WW, Zang ZD, Wang L, Fu XL. Supplemental Fuzhenghuayu capsule therapy for improving liver fibrosis markers in patients with chronic hepatitis B following unsatisfactory outcome of nucleos(t)ide analogue monotherapy. Zhonghua Gan Zang Bing Za Zhi. 2013;21(7):514

104. Liu C, Hu Y, Xu L, Liu C, Liu P. Effect of Fuzheng Huayu formula and its actions against liver fibrosis. Chin Med. 2009;4:12.

105. Li QY, Guo ZZ, Deng X, Xu LM, Gao YQ, Zhang W, et al. Curative Effects of ZHENG-Based Fuzheng-Huayu Tablet on Hepatitis B Caused Cirrhosis Related to CYP1A2 Genetic Polymorphism. Evid based Complement Altern Med. 2013;2013:302131

106. Cai HB, Sun XG, Liu ZF, Liu YW, Tang J, Liu Q, et al. Effects of dahuangzhechong pills on cytokines and mitogen activated protein kinase activation in rats with hepatic fibrosis. J Ethnopharmacol. 2010;132(1):157.

107. Yang FR, Fang BW, Lou JS. Effects of Fufang Biejia Ruangan pills on hepatic fibrosis in vivo and in vitro. World J Gastroenterol. 2013;19(32):5326.

108. Chen JM, Yang YP, Chen DY, Han J, Jin XY, Huang ZX, et al. Efficacy and safety of Fufang Biejia Ruangan tablet in patients with chronic hepatitis B complicated with hepatic fibrosis. Zhonghua Shi Yan He Lin Chuang Bing Du Xue Za Zhi. 2007;21(4):358.

109. Loguercio C, Andreone P, Brisc C, Brisc MC, Bugianesi E, Chiaramonte M, et al. Silybin combined with phosphatidylcholine and vitamin $E$ in patients with nonalcoholic fatty liver disease: a randomized controlled trial. Free Radic Biol Med. 2012:52(9):1658.

110. Di Sario A, Bendia E, Taffetani S, Omenetti A, Candelaresi C, Marzioni M, et al. Hepatoprotective and antifibrotic effect of a new silybinphosphatidylcholine-Vitamin E complex in rats. Dig Liver Dis. 2005;37(11):869.

111. Silveira MG, Lindor KD. Obeticholic acid and budesonide for the treatment of primary biliary cirrhosis. Expert Opin Pharmacother. 2014;15(3):365.

112. Mudaliar S, Henry RR, Sanyal AJ, Morrow L, Marschall HU, Kipnes M, et al. Efficacy and safety of the farnesoid $X$ receptor agonist obeticholic acid in patients with type 2 diabetes and nonalcoholic fatty liver disease. Gastroenterology. 2013;145(3):574.

113. Chen CC, Huang LT, Tain YL, Chaung HC, Hsieh CS, Eng HL, et al. Reduced brain content of arachidonic acid and docosahexaenoic acid is related to the severity of liver fibrosis. Dig Dis Sci. 2010;55(10):2831.

114. Depner CM, Philbrick KA, Jump DB. Docosahexaenoic acid attenuates hepatic inflammation, oxidative stress, and fibrosis without decreasing hepatosteatosis in a Ldlr(-/-) mouse model of western diet-induced nonalcoholic steatohepatitis. J Nutr. 2013;143(3):315.

115. Chu AS, Diaz R, Hui JJ, Yanger K, Zong Y, Alpini G, et al. Lineage tracing demonstrates no evidence of cholangiocyte epithelial-tomesenchymal transition in murine models of hepatic fibrosis. Hepatology. 2011;53(5):1685.

116. Kisseleva T, Cong M, Paik Y, Scholten D, Jiang C, Benner C, et al. Myofibroblasts revert to an inactive phenotype during regression of liver fibrosis. Proc Natl Acad Sci U S A. 2012;109(24):9448.

117. Velayudham A, Dolganiuc A, Ellis M, Petrasek J, Kodys K, Mandrekar P, et al, VSL\#3 probiotic treatment attenuates fibrosis without changes in steatohepatitis in a diet-induced nonalcoholic steatohepatitis model in mice. Hepatology. 2009;49(3):989.

118. Toda K, Kumagai N, Kaneko F, Tsunematsu S, Tsuchimoto K, Saito H, et al. Pentoxifylline prevents pig serum-induced rat liver fibrosis by inhibiting interleukin-6 production. J Gastroenterol Hepatol. 2009;24(5):860.

119. Xia JL, Dai C, Michalopoulos GK, Liu Y. Hepatocyte growth factor attenuates liver fibrosis induced by bile duct ligation. Am J Pathol. 2006;168(5):1500.

120. Clouthier DE, Comerford SA, Hammer RE. Hepatic fibrosis, glomerulosclerosis, and a lipodystrophy-like syndrome in PEPCK-TGF-beta1 transgenic mice. J Clin Invest. 1997;100(11):2697.

121. Barikbin R, Neureiter D, Wirth J, Erhardt A, Schwinge D, Kluwe J, et al. Induction of heme oxygenase 1 prevents progression of liver fibrosis in Mdr2 knockout mice. Hepatology. 2012;55(2):553.

122. Xu Z. Modernization: One step at a time. Nature. 2011;480(7378):\$90

123. Choi JH, Jin SW, Kim HG, Khanal T, Hwang YP, Lee K, et al. Platycodi Radix attenuates dimethylnitrosamine-induced liver fibrosis in rats by inducing Nrf2-mediated antioxidant enzymes. Food Chem Toxicol. 2013;56:231. 